\title{
Enhancing Public Services Quality by Strengthening the Role of Ombudsman
}

\author{
Yuli Tirtariandi El Anshori \\ Department of Public Administration \\ Universitas Terbuka \\ South Tangerang, Indonesia \\ yulitirta@ecampus.ut.ac.id
}

\author{
Enceng \\ Department of Public Administration \\ Universitas Terbuka \\ South Tangerang, Indonesia \\ enceng@ecampus.ut.ac.id
}

\begin{abstract}
Good public services have been very significant issues nowadays. All government agencies should conduct best service to serve the public. In fact, there are many complaints due to the delivery of public services by the agencies. It includes the matter of time, procedures, and costs. Sometimes the public service delivery raises a dispute or conflict. It is not easy for citizens to have fairness when they involved in a dispute with the government. Thus, it requires a guard to watch the implementation of public services. The guard is Ombudsman that has the authority. Ombudsman in Indonesia is established based on the Law No. 37/2008 about The Ombudsman of Republic Indonesia. This article discusses the role of Ombudsman in Bangka Belitung Province in Indonesia to overcome the public services dispute cases. The research method is qualitative approach. Data are collected through interview, observation, and documentary study. The result shows that the Ombudsman has a very huge authority to mediate a public service dispute. On the other side, it has some obstacles such as the authority to make a recommendation. It is only able to make a draft and the national Ombudsman makes the final approval. The other constraints are the human resources, the leadership style, and limited budget.
\end{abstract}

Keywords: ombudsman; public services; authority; leadership

\section{INTRODUCTION}

Efficient and effective public services have become the public demand for government agencies today. The Public Service Law is one of the standards in the delivery of public services, including the Minimum Service Standards or Standard Operating Procedures established by each institution. Almost every year the government also carries out various competitions related to public services provided by the bureaucracy. However, it is rare for bureaucrats to be punished or sanctioned for providing poor and unqualified public services. Whereas, the public deserve effective services (quality) and efficient services (saving time, energy, and cost).

A critical society will dare to speak out if it gets poor public service. They can use various media of complaints such as a complaint box, fill out an e-complaint form through an institution's website, or submit their complaints through social media and mass media. However, not all of the complaints are responded quickly and well by the relevant institutions. One of the institutions that can actually be used by users of public services is the Ombudsman of the Republic of Indonesia (ORI). Some communities do not seem to understand the functions and tasks of ORI, especially very rarely we hear cases handled by ORI really responded and resolved by the agencies. In Article 1 of Law no. 37 of 2008 on the Ombudsman of the Republic of Indonesia stated that the Ombudsman is a state institution that has the authority to oversee the implementation of public services both organized by state and government organizers including those held by State-Owned Enterprises, Regional Government Enterprises and State-Owned Legal Entities as well as private bodies or individuals assigned to perform certain public services which part or all of their funds are sourced from the state revenue and expenditure budget and / or regional revenue and expenditure budget. It can be concluded that ORI has wide authority in overseeing the implementation of public services.

One of the interesting things is the Article 10 of the Law that states "In the course of the performance of its duties and authorities, the Ombudsman cannot be arrested, detained, interrogated, prosecuted or sued in court". This indicates that ORI as a supervisory agency is given a very large space in carrying out its duties and authorities without fear of criminalization. The number of public service cases reported to ORI until December 2014 reached 6,180 reports. This number increased compared to the year 2013 which only reached 5,173 reports.

Then, from the side of the reporting agency, local government gets complaints from the community as much as 43.7 percent. The rest are central/vertical government agencies. Based on the data, 77.7 percent of complainants reported service from the district/municipality governments, 12.1 percent of provincial governments, 2.6 percent of sub-district governments, 5 percent of urban administrations, and 2.6 percent of village governments. Besides, the four most prevalent maladministration services of agencies are the prolonged postponement (25.4 percent), procedural deviations 
(20.3 percent), not-serving (13.9 percent), and abuse of authority (11.7 percent).

Based on the substances, the most complaints are the civil servants 16 percent, 12.9 percent is the land case, 11.8 percent concerning police issues, and education cases 11.1 percent. In 2015, The number of public service cases reported to ORI were 6,589 reports, but only 3,255 reports had been finished in the same year. In 2015 , it was about $41.59 \%$ or 2,853 reports concerning the local government. Last year (2016), the number of reports received by ORI were 9,030. The local government still ranked the first with $40 \%$ reported. Ombudsman itself was established in Indonesia in the era of President K.H. Abdurrahman Wahid. Beginning with Presidential Decree No. $55 / 1999$ on the assessment team of the establishment of the Ombudsman institution.

The background of the need to establish an Indonesian Ombudsman institution is to improve the provision of protection of the rights of community members from state administrators who are inconsistent with their legal obligations, by giving opportunity to disadvantaged community members to complain to an independent institution known as Ombudsman. Then based on Presidential Decree No. 44 of 2000, the National Ombudsman Commission (KON) was established. On October 7, 2008, it was stipulated the Law of the Republic of Indonesia Number 37 about Ombudsman of the Republic of Indonesia.

The National Ombudsman Commission is changed to Ombudsman of the Republic of Indonesia (ORI). It affirms that the Ombudsman is no longer a temporary State Commission, but a permanent state institution as well as other state institutions, and free from the interference of another agencies' power. In the province of Bangka Belitung itself, accompanied $\mathrm{KON}$ at the central level, there were Ombudsman of Bangka and Ombudsman Commission of Pangkalpinang City. While at the provincial level there was no ombudsman representatives.

In 2008, the Ombudsman in Bangka Regency and Pangkalpinang City were dissolved. Then in 2013, ORI representatives of Bangka Belitung Province officially established. However, until 2016, there is no Ombudsman representative at the district or city level. It is interesting to examine whether the Ombudsman is quite up only to the provincial level, or it is urgent to establish Ombudsman at the city level. This refers to the facts that as many as 77.7 percent of complainants' report service from the district / city government.

Throughout the year 2014 the Ombudsman Representative of Bangka Belitung has received 144 complaints or reports from the public on the dissatisfaction of public servants' performance. It decreased to 120 cases in the next year. In 2016 the number of public service complaints increased again to 136 cases. Based on the background, the problem in this research is "how is the role of the Ombudsman of the Republic of Indonesia representatives of the Province of Bangka Belitung to settle disputes of public services? Then, should the Ombudsman be established at the district/city level in the province of Bangka Belitung?

\section{RESEARCH METHOD}

This article uses qualitative method with explorative model. Data collection techniques are in-depth interviews, documentary studies, field observations [3]. Qualitative data analysis is conducted to explore the phenomenon.

\section{RESULT AND DISCUSSION}

The authority of the Ombudsman Representative is regulated in Article 7 of PP No.21/2011, e.g.:

a) Requesting verbal and/or written information from the Reporting Party, Reported Party, or other related parties concerning Reports submitted to Ombudsman Representative

b) Examining decisions, correspondence, or other documents contained in the Reporting Party or the Reported Party to obtain the truth of a Report;

c) Asking for clarification and / or copies or photocopies of necessary documents from the agency anywhere for the Reporting or Reported Party. the purpose of ORI establishment is to create a democratic, fair and prosperous legal state; encourage effective and efficient, honest, open, and clean government, free from corruption, collusion and nepotism. It then improves the quality of state services in all areas so that every citizen obtains justice, security, and better welfare; helping to increase efforts to eradicate and prevent maladministration, discrimination, collusion, corruption, and nepotism practices.

To carry out its functions, duties and authorities, ORI Representatives of Bangka Belitung has made many settlements of maladministration cases of public services. For example, in the case of the exercise of authority, namely to request information verbally or written from the reported agency. The Ombudsman uses two ways of approaching or requesting the reported party to come to the office of ORI Representative. Cultural approach of the community that is put forward in the settlement of maladministration case. It was expressed by the Head of ORI Representative. This adjusts to the situation and condition as well as the character of the community.

Currently, there is also another legal basis that strengthens the role of Ombudsman. It is Presidential Regulation no. 76 issued in 2013 on Public Service Complaint Management as a follow up of other rules such as the Public Service Law. In Article 12 paragraph (3) of Presidential Decree No. 76/2013, it is stated that the deadline for settlement of public complaints by public service providers is 60 days. In fact, it is very rare the complaint be followed up within 60 days. Thus, the community began to switch to the Ombudsman to deliver their complaints. Nevertheless, there were a few people who use the existence of Ombudsman Representative Agency at the beginning of August 2013 due to several things. For example, because of the lack of socialization from the Ombudsman itself.

There is also a presumption that the Ombudsman is less responsive to the report of the community. It is because of the mechanism. The citizen should complain his case to the head of the relevant agencies, then report it to the Ombudsman. In the case of recommendation, the Representative Ombudsman does not have the authority to issue his own recommendation as he is an extension of the Central Organization. The Representative 
Ombudsman only be able to make the draft and then submit to the ORI Center which will issue a recommendation. Theoretically, one of the dimensions that must be considered to improve the organizational performance of Ombudsman as public servant is the external environment. Within this dimension is the regulatory indicator.

It is also affirmed by the Ombudsman Chairman that the Ombudsman is not giving sanctions but only making recommendations. From these explanations, it can be seen that the authority of Ombudsman Representative is severely constrained by existing regulations.

Meanwhile, the substance of the report of the community to the Ombudsman representative can be seen in the following table:

Table 1. Kind of Reports to Ombudsman Representative 2014-2016

\begin{tabular}{|c|c|c|}
\hline Years & Kind of Reports & Total \\
\hline 2014 & $\begin{array}{ll} & \text { Public Information } \\
\text { - } & \text { Staffing } \\
\text { - } & \text { Health } \\
\text { - } & \text { Police } \\
\text { - } & \text { Licensing } \\
& \text { Land } \\
\end{array}$ & $\begin{array}{c}20 \\
17 \\
10 \\
7 \\
12 \\
9\end{array}$ \\
\hline 2015 & $\begin{array}{ll}\text { - } & \text { Electricity } \\
\text { - } & \text { Land } \\
\text { - } & \text { Education } \\
\text { - } & \text { Licensing } \\
\text { - } & \text { Staffing } \\
\text { - } & \text { Police } \\
\end{array}$ & $\begin{array}{c}15 \\
15 \\
8 \\
5 \\
5 \\
5\end{array}$ \\
\hline 2016 & $\begin{array}{ll}\text { - } & \text { Public Information } \\
\text { - } & \text { Staffing } \\
\text { - } & \text { Health } \\
\text { - } & \text { Police } \\
\text { - } & \text { Licensing } \\
\end{array}$ & $\begin{array}{r}6 \\
14 \\
20 \\
9 \\
1 \\
12 \\
\end{array}$ \\
\hline
\end{tabular}

Source: Ombudsman Representative Bangka Belitung Province

Based on table 1, it can be analyzed that the substance of the report that the public always complains every year and the amount is quite large is the problem of land, licensing, staffing, and police. As stated by the Chairman of Ombudsman Representative, the land issue has been reported several times by citizens. After they complained to the Ombudsman, the land certificate of citizens finally finished. The response from vertical institutions is quicker in responding to cases of alleged maladministration than the local agencies.

Referring to organizational theory [7], ORI needs to address dynamic environmental changes. This is in line with partnerships strategy [1]. In addition, the authority of the Ombudsman is limited because it can only provide recommendations rather than direct sanctions. In reality, the partnership established by the Ombudsman Representative of Bangka Belitung has not been running with all the local governments. This becomes something that needs to be done in the future by the Ombudsman Representative. The existence of a formal partnership will encourage the learning process for the relevant government apparatus.

\section{A. Supporting and Inhibiting Factors}

To undertake its authority, the Ombudsman Representative has several supporting and inhibiting factors. The supporting factors are the cooperative attitude shown by the agencies in the local government and vertical institutions. Then, the success of the Ombudsman to resolve various cases that had been hanging over the years, encouraging the public to be more confident with the work of Ombudsman Representative. It was stated by the respondents in terms of the success of case settlements that had been unfinished for years. For example, the birth certificate management that had not been completed for years. When the concerned citizen reported to the Ombudsman, the problem could be resolved quickly. So, the complainant would tell others about the success of his case. The complainant also felt happy because it was free of charge.

Meanwhile, there are some obstacles. First, some of the staffs have not been able to carry out the task by promoting local cultural approach. Performance of a public organization's services can be increased by paying enough attention to the problem of culture, both internal and external organization [1]. Second, the funding constraint. The Ombudsman Representative only get fund allocation 300 million rupiahs per year. This is felt to hinder the performance of Ombudsman Representative of the Province of Bangka Belitung. For example, in the implementation of socialization to the community.

Consequently, there are still people who are not yet aware of the existence of the Ombudsman Representative and initially had a negative image of the Ombudsman. In addition to budget constraint, another obstacle for The Ombudsman Representative of the Province of Bangka Belitung is human resources issue. Currently, besides the Head of the Ombudsman Representative, there are 5 assistants. Other employees are 1 civil servant and 1 non-permanent employee in the Ombudsman Secretariat, and 1 security personnel.

Nevertheless, the leadership factor occupies an important factor in improving the performance of an organization [1]. Although there has been a specialization of work [5], but in practice, the Ombudsman Representative still carries out the implementation of working collectively. On one hand, this gives a positive impact that is the learning process for the staffs. But on the other hand, this can negatively impact the lack of initiative or innovation of the staffs. This is similar to the case of Mohtasib-e-Punjab Ombudsman in India [6]. It was found that the lack of resources and qualified staff is the main cause of ineffectiveness and inefficiency of Ombudsman of Punjab.

\section{B. Level of Service Satisfaction}

The Ombudsman in Bangka Belitung has never conducted an internal survey to measure citiziens' satisfaction. It concludes that the clients have been satisfied because there are no cases unsolved. The rate of cases completion reaching 100 percent by 2014 and 2015 , and $87 \%$ by the end of 2016 . This indicates that the Ombudsman Representative of the Province of Babylon has not fully addressed the heterogeneous and dynamic environmental changes as [7] points out.

Types of alleged maladministration cases reported to ORI Representatives include: illegal levies, retirement, 
handling of tangled land certificates, granting permits without involving public participation, compensation of land, and behavior of public servants. Almost all respondents that were interviewed by researcher stated that cases reported to Ombudsman Representative could be resolved, except for one case on behavior of general hospital employees revoked the report because it was completed through mediation with family initiation. In that case, between the complainant and the reported party still have family ties.

For tangible dimension, in particular physical facility completeness indicators, all respondents stated physical completeness is good. The availability of service equipment, the number of proportional employees are also in good category, as well as the number of communication tools owned by The Ombudsman. Then, the dimension of reliability particularly the employee performance indicator and service quality, all respondents stated good. Next dimension namely responsiveness, when viewed from employee readiness to provide services. all respondents stated also good.

In terms of the speed of service, all respondents stated good too. How about assurance dimension? The indicators are employee skills, community-friendly attitude, all respondents stated good. Last dimension namely the empathy aspect, in terms of ease in contacting employees, anticipating community needs, and employee responsiveness to community complaints, all respondents stated good.

However, Gadlin [2] said that assessments of ombudsman effectiveness should not be governed only by consideration of cost-effectiveness, nor by measures that demonstrate "customer" satisfaction. Instead, it is argued that there should be a parallel between the standards for designing an ombudsman program and the dimensions along which an ombudsman program is evaluated. Any assessment of an ombudsman program ought to provide infor- mation that helps the ombudsman staff improve the quality of their work and the effectiveness of ombudsman program. One of best practices is The Ombudsman of Makassar City in Indonesia. A study by Juharni [4] revealed that Ombudsman of Makassar showed effectiveness in carrying out its role, tasks, and functions.

\section{Establishing Ombudsman in Regencies/Cities}

As previously described, in the era before the ORI was formed, in Bangka Belitung there have been two Regional Ombudsman Commission (KOD) in Bangka and Pangkalpinang. Particularly in Kabupaten Bangka, according to former Ombudsman Commission member, Hendra Sinaga, there were about 100 cases that had handled by The Ombudsman of Bangka Regency for 5 years. If the Ombudsman is re-established at the district or city level then it is expected that more cases of maladministration can be dealt with. According to him, if the ombudsman is founded at the district or city level, the citizens will be easier to obtain information and to complain to the Ombudsman.

In the era of the Bangka Ombudsman, it was very pro-active down to the community to collect complaints from the community. They had many working programs per sub-district, regularly met the sub-district and village heads on schedule. Currently, residents' access distance if they have to come to the
ORI representative in Pangkalpinang City is too far. Referring to the Law 37/2008, the formation of Ombudsman Representative at the district / city level can be done if it is felt necessary. Regarding this matter, the Head of Ombudsman of the Representative of Bangka Belitung said that the fulfillment is done gradually.

Establishment of ORI Representatives are conducted at the provincial level first, then in districts and cities based on the decision of the Central Ombudsman. This is by considering the issue of human resources and budget and listening to input from the Provincial Ombudsman. Establishment of district-level Ombudsmen in Bangka Belitung is possible but is unlikely to be implemented in the short time due to budget and human resource constraints. It is a critical fact that the number of complainants from Bangka Regency and Pangkalpinang City has dominated over the last 3 years. This may be due to the relatively close distance to the Ombudsman Representative office of Bangka Belitung.

The large number of complainants coming from Bangka Regency can open the possibility to open ORI Representative in the regency considering the enthusiasm of its citizens towards the existence of ORI. As stated by former member of Ombudsman Bangka Hendra Sinaga, when the Ombudsman still stood in Bangka Regency, it also served many cases of public services that are not directly related to government fund. For example, cases related to the welfare of workers of a palm oil company in Bangka Regency. The case was initially handled solely by the government agency of Bangka Regency which was faced with the management of the company and the labours. When the negotiation was deadlocked and an indication of maladministration was found, the Ombudsman was involved and acted as a mediator for other 3 parties, ie. labour union, management and the local government. The recommendations given by the Ombudsman were finally acceptable to the employer and the welfare of the workers is met. In line with the theory proposed by [7 ], the environment will affect the design of an organization. It can be analyzed in terms of this Ombudsman institution.

An organization as the Ombudsman needs to adapt to his environment because the environment is always dynamic. Similarly, it is expressed by [1] that the performance of the services of a public organization is strongly influenced by a complex and dynamic external environment. In the context of ORI institutions, ORI in the future also needs to adjust its role and authority, related to the handling of maladministration cases that are not related to the use of central or local government funds. Nevertheless, this adjustment of roles and authority is highly depends on the legal frame on which ORI's task and function is based on the Law.

Regarding the discourse of the establishment of ORI Representative in Bangka Regency, it needs a strong political commitment from local government to make Ombudsman can be formed. Theoretically, according to [5], one of the structural dimensions of organizational design is centralization. The current ORI organizational design particularly in the Province of Bangka Belitung that is only established at the provincial level needs to be analyzed further to see its effectiveness. The principle of centralization applied by the Ombudsman at this 
time needs to be analyzed deeply whether it makes the performance of Ombudsman in Bangka Belitung Province easier or more difficult.

The results of interviews with 30 respondents who have reported cases of alleged maladministration to the Ombudsman Commission of Bangka Regency at the past time, showing data types and number of maladministration reports ever handled by Ombudsman of Bangka Regency include: land compensation, health services, delay in delivering service, salary delays, unilateral dismissal of contract workers, certificate handling, and land acquisition.

All reported cases can be completed by Ombudsman of Bangka, either with a mediation or recommendation pattern. Among the cases, prominent cases reported by the respondents were land compensation and licensing service cases. All respondents stated knowing the existence of Ombudsman of Bangka Regency through socialization done by this institution, distribution of pamphlet and media publication and agenda of activity executed by Ombudsman of Bangka Regency. All respondents have reported their cases through various reports as described above.

All respondents express the attention and response given by ombudsman's staff to the problem which is very well complained in terms of attention and response by following up the problems so as to realize the real solution, so that all the respondents are satisfied with the service provided by Ombudsman Commission of Bangka Regency. The respondents also stated the need to re-establish Ombudsman Commission of Bangka Regency because it helps the community to solve the problem. In terms of appearance of personnel, the public was not shy and burdened because the staffs of Ombudsman of Bangka Regency were not uniformed so that the impression of populist profile more illustrated.

\section{CONCLUSION}

Based on the previous description, it can be concluded that the authority possessed by the Ombudsman Representative of the Province of Bangka Belitung is very large because it is protected by law. For example, Ombudsman can call forcibly the reported party if denying until three times. Then the Ombudsman can report the parties who do not implement the recommendations from the ombudsman. The report can be delivered to President of Indonesia and The House of Representatives.

This shows that the Ombudsman has considerable authority as mandated by the Law. With such great authority, the role played by the Ombudsman Representative of the Province of Bangka Belitung for the last two years can satisfy the complainants. Nevertheless, there are obstacles in the exercise of such authority for the Ombudsman of the Representative of Bangka Belitung. It is still strongly bounded by existing regulations in exercising its authority. Then the level of satisfaction of the reporting community services shows at a good level. This is due to the case resolution index reaching 100 percent in 2014 and 2015.

Nevertheless, the community requested the Ombudsman Representative of Bangka Belitung to be more pro-active in socializing and solving the cases. While the discourse of forming Ombudsman at the district / city level, this can be done if the budget and available human resources are adequate. This is urgent to consider because the number of whistleblowers coming from outside the city where the Ombudsman Representative Office resides showing an increasing trend. If the Ombudsman's office is re-established at the district level it will further improve service to the community.

\section{ACKNOWLEDGMENT}

This work was supported by Research and Community Services Institute of Universitas Terbuka through its fundamental research program.

\section{REFERENCES}

[1] G. Boyne, and R. Asworth, Public Service Improvement: Theories and Evidence. New York: Oxford Universty Press, 2010

[2] H. Gadlin, "Assesing Efectiveness in Ombudsman Programs," Journal of The Ombudsman Assosiation, vol. 3, pp. 24-27, April 2010

[3] J. Creswell, Research Design: Qualitative, Quantitative and Mixed Approaches (Research Design; Pendekatan Kualitatif, Kuantitatif, dan Mixed). Yogyakarta: Pustaka Pelajar, 2010.

[4] R. Juharni, and H. Akib, "The Effectiveness a Role of the Ombudsman's Makassar," Mediterranean Journal of Social Sciences, vol. 7, May 2016

[5] R. Daft. Organization Theory and Design, 10th edition. Ohio, USA: South-Western Cengage Learning, 2009

[6] S. Bukhari, and M. Asif, "Institutional Analysis of Ombudsman (A Comparative Study of Pakistan, India, UK, and USA)," Interdisciplinary Journal of Contemporary Research in Bussiness, vol. 5, pp. 709-726, Juni 2013.

[7] T. Christensen, P. Laegreid, and P. Roness, Organization Theory and The Public Sector: Instrument, Culture and Myth. New York: Routledge, 2007 